\title{
Implementasi Model Pembelajaran Kooperatif Tipe Group Investigation untuk Meningkatkan Hasil Belajar pada Mata Pelajaran Simulasi Digital
}

\author{
Komang Adia \\ Smk Negeri 1 Sukasada \\ e-mail: KomangAdila234.co.id
}

\begin{abstract}
Abstrak
Penelitian ini bertujuan untuk mengetahui peningkatan hasil belajar siswa SMK Negeri 1 Sukasada pada mata pelajaran simulasi digital melalui implementasi model Pembelajaran Kooperatif Tipe Group Investigation. Jenis penelitian ini adalah tergolong penelitian tindakan kelas. Penelitian dilaksanakan sebanyak 2 siklus. Subyek penelitian adalah siswa Kelas X MM2 SMK Negeri 1 Sukasadayang berjumlah 36 siswa. Data dianalisis menggunakan statistik deskriptif.Berdasarkan hasil penelitian didapatkan hasil belajarsiswa pada mata pelajaran simulasi digital siklus I sebesar 61,11\% (aspek kognitif), 83,33\% (aspek afektif), dan $80,56 \%$ (aspek psikomotorik)yang tergolong cukup baik serta di siklus II sebesar $86,11 \%$ berada dalam kategori baik (aspek kognitif), kategori baik (aspek afektif), dan kategori baik (aspek psikomotorik), mengalami peningkatan antara siklus I ke siklus II secara klasikal sebesar $25 \%$. Berdasarkan hasil analisis data dan pembahasan, dapat disimpulkan bahwa hasil belajar siswa pada mata pelajaran simulasi digitalmeningkat melalui implementasi model pembelajaran Kooperatif Tipe Group Investigation pada siswa kelas X MM2 SMK Negeri 1 Sukasada tahun pelajaran 2018/2019. Disarankan kepada guru simulasi digital agar mengimplementasikan model pembelajaran Kooperatif Tipe Group Investigation karena terbukti dapat meningkatkan hasil belajar pada mata pelajaran simulasi digital.
\end{abstract}

Kata Kunci: Kooperatif tipe Group Investigation, Hasil Belajar, Simulasi Digital.

\begin{abstract}
This study aims to determine the increase of student learning outcomes at SMK Negeri 1 Sukasada on digital simulation subjects through the implementation of Cooperative Learning Type Group Investigation model. This type of research classified as classroom action research. The study conducted in 2 cycles. The research subjects were $X$ grade syudents of X MM2 at SMK Negeri 1 Sukasada which amounted to 36 students. The data were analyzed using descriptive statistics. Based on the results of the study, the results of the study showed that students in digital simulation subjects in the first cycle were $61.11 \%$ (cognitive aspects), $83.33 \%$ (affective aspects), and $80.56 \%$ (psychomotor aspects) which were sufficient good and in the second cycle of $86.11 \%$ in the good category (cognitive aspects), good categories (affective aspects), and good categories (psychomotor aspects), experienced an increase between cycle I to cycle II classically by $25 \%$. Based on the results of data analysis and discussion, it can be concluded that student learning outcomes in digital simulation subjects increased through the implementation of the Cooperative Group Investigation Learning model in X grade pf MM2 SMK Negeri 1 Sukasada in 2018/2019 academic year. It is recommended to digital simulation teachers to implement the Cooperative Group Investigation learning model because it was proven to improve learning outcomes in digital simulation subjects.
\end{abstract}

Keywords: Cooperative type of Group Investigation, Learning Outcomes, Digital Simulation. 


\section{Pendahuluan}

Pendidikan merupakan usaha sadar dan terencana untuk mewujudkan suasana dan proses pembelajaran dimana peserta didik dapat mengembangkan potensi dirinya secara aktif. Pendidikan tidak terlepas dari istilah pembelajaran karena pembelajaran merupakan proses interaksi peserta didik dengan pendidik pada lingkungan belajar yang bertujuan untuk memperoleh pengetahuan dan keterampilan. Proses pembelajaran akan berpengaruh terhadap hasil belajar yang diraih oleh peserta didik. Proses pembelajaran yang baik dan berkualitas akan membantu siswa untuk lebih mudah mencapai hasil belajar yang baik. Agar memberi hasil yang baik maka kegiatan pembelajaran harus dilakukan secara interaktif, menyenangkan, menginspirasi siswa, menantang, memotivasi secara aktif, memberi ruang bagi kreativitas dan kemandirian siswa sesuai dengan bakat, minat, dan perkembangan fisik serta psikologis peserta didik.

Pendidikan merupakan suatu proses yang diperlukan untuk mendapatkan keseimbangan dan kesempurnaan dalam perkembangan individu maupun masyarakat. Penekanan pendidikan dibanding dengan pengajaran terletak pada pembentukan kesadaran dan kepribadian individu atau masyarakat di samping transfer ilmu dan keahlian. Dengan proses semacam ini suatu bangsa atau negara dapat mewariskan nilai-nilai keagamaan, kebudayaan, pemikiran dan keahlian kepada generasi berikutnya, sehingga mereka betul-betul siap menyongsong masa depan kehidupan bangsa dan negara yang lebih cerah (Nurkholis ,2013).

Mata pelajaran Simulasi Digital merupakan salah satu mata pelajaran yang diterima oleh kelas X kompetensi keahlian Multimedia di SMK Negeri 1 Sukasada. Simulasi Digital merupakan mata pelajaran baru yang dirancang untuk menggantikan mata pelajaran KKPI pada tingkat SMK/MAK. Materi yang diajarkan pada mata pelajaran Simulasi Digital dititikberatkan pada pembelajaran kolaboratif yang memanfaatkan perkembangan teknologi. Sebagai mata pelajaran yang memiliki konsep pemanfaatan teknologi untuk kemudahan belajar siswa, proses pembelajaran Simulasi Digital dirancang agar berlangsung secara interaktif, menyenangkan, dan memberi ruang bagi siswa untuk terlibat secara aktif dan kreatif. Namun dalam pelaksanaannya, proses pembelajaran Simulasi Digital masih menemui banyak permasalahan yang datang baik dari siswa maupun guru.

Kemampuan belajar siswa dapat dilihat dari penilaian hasil belajar sesuai standar kelulusan yang berlaku.Penilaian hasil belajar digunakan untuk menilai pencapaian Standar Kompetensi Lulusan. Sesuai Permendikbud No 104 tahun 2014 Pasal 9 Ayat (2) dan (3) tentang Penilaian Hasil Belajar oleh Pendidik pada Pendidikan Dasar dan Pendidikan Menengah, dijelaskan bahwa skor rerata ketuntasan kompetensi pengetahuan ditetapkan paling kecil 2,67 dan ketuntasan kompetensi keterampilan ditetapkan paling kecil 2,67. Sedangkan ketuntasan klasikal dalam satu kelas adalah $75 \%$ dari jumlah siswa per kelas.Berdasarkan hasil observasi, ketuntasan klasikal kelas X SMK N 1 Sukasada Tahun Ajaran 2018/2019 masih jauh dari standar ketuntasan klasikal. Hasil belajar kelas X pada ulangan tengah semester adalah $46 \%$ tuntas dan $54 \%$ tidak tuntas. Dari hasil tersebut, maka diperlukan upaya perbaikan pembelajaran agar hasil belajar siswa dapat meningkat.

Ada beberapa faktor yang dapat diidentifikasi sebagai penyebab rendahnya hasil belajar siswa di kelas. Permasalahan yang datang dari siswa adalah kesadaran siswa untuk belajar dan berpartisipasi secara aktif dalam kegiatan belajar-mengajar yang terbilang masih kurang. Dalam kegiatan belajar-mengajar, hanya sedikit siswa yang berpartisipasi aktif seperti bertanya ataupun mengajukan pendapat. Siswa juga cenderung kurang melakukan interaksi aktif dengan guru dan siswa lainnya. Proses belajar dilakukan secara individual dimana setiap siswa memegang satu laptop atau komputer dan melakukan praktik secara perseorangan. Proses belajar secara individu tersebut kurang efektif karena kebanyakan siswa kemudian kehilangan fokus untuk belajar dan menyalahgunakan fasilitas yang digunakan untuk membuka media sosial, bermain game, dan mengerjakan tugas mata pelajaran lain. Sedangkan apabila dilakukan pembelajaran dimana siswa diminta untuk saling berdiskusi, kebanyakan siswa cenderung pasif dan hanya siswa-siswa tertentu yang aktif mencari pemecahan permasalahan, menyampaikan pendapat, bertukar pikiran, maupun bertanya kepada guru. Hal tersebut mengakibatkan hanya siswa-siswa tertentu itulah yang benar-benar memahami materi yang diberikan oleh guru.

Selain dari siswa, permasalahan dalam proses belajar-mengajar juga berasal dari guru yang bersangkutan. Dalam menyampaikan materi, guru hanya menggunakan metode ceramah berbantuan media presentasi. Metode tersebut bagi siswa dianggap kurang menarik sehingga mengakibatkan siswa cenderung kurang memperhatikan materi yang disampaikan dan 
melakukan kegiatan lain yang tidak berhubungan dengan materi pelajaran. Selain itu, bagi siswa guru masih dianggap sebagai satu-satunya sumber belajar sehingga siswa cenderung malas untuk aktif mencari sumber belajar lainnya dan malas mengeksplorasi materi yang diperoleh. Implikasi dari pembelajaran seperti ini berujung pada rendahnya hasil belajar siswa di kelas.

Solusi untuk mengatasi permasalahan tersebut adalah dengan menerapkan model pembelajaran yang menarik, memotivasi, dapat meningkatkan partisipasi dan keaktifan siswa serta membiasakan siswa untuk saling bekerjasama dalam proses pembelajaran. Model pembelajaran yang sesuai dengan kebutuhan di atas adalah model pembelajaran kooperatif. Model pembelajaran kooperatif mengutamakan adanya kerjasama kelompok untuk mencapai tujuan pembelajaran. Dalam prosesnya, siswa dilibatkan secara aktif baik saat bekerja secara individual maupun saat bekerjasama dengan siswa lain sehingga dapat merangsang siswa agar lebih termotivasi dalam belajar. Salah satu tipe dalam model pembelajaran kooperatif yang dapat diterapkan untuk mengatasi permasalahan tersebut adalah tipe investigasi kelompok (Group Investigation). Group Investigation merupakan perencanaan pengaturan kelas dimana siswa bekerja sama dalam kelompok kecil untuk berdiskusi dan perencanaan proyek kooperatif (Slavin, 2005: 24). Tipe ini menitikberatkan pada partisipasi dan kerja sama siswa secara berkelompok dalam mencari informasi dari berbagai sumber baik dari buku maupun internet.

Penggunaan model pembelajaran yang tepat dan bervariasi dapat meningkatkan motivasi siswa karena hal itu dapat meningkatkan hasil belajar siswa. Guru harus dapat menerapkan berbagai model pembelajaran yang efektif serta menarik bagi siswa dalam proses pembelajaran sesuai dengan situasi dan kondisi. Kurangnya minat guru dalam memilih model pembelajaran karena menganggap bahwa proses pembelajaran sebagai satu-satunya alternatif hanya dengan ceramah yang mengharapkan siswa duduk, diam, mendengar, mencatat, menghafal dan mendapatkan hasil yang baik namun demikian hasil yang di inginkan kurang memuaskan sehingga pencapaian kompetensi kurang optimal (Saptadi ,2016).

Group Investigation atau investigasi kelompok diperlukan kecakapanberkomunikasi yang baik.Keberhasilan investigasi kelompok tergantung pada kemampuan berkomunikasi yang baik dan kemampuan sosial yang dilakukan sebelumnya (Nur Asma, 2006: 61). Komunikasi dilakukan untuk bertukar informasi dengan kelompok lain dengan cara merepresentasikan hasil diskusi kelompok. Dalam mata pelajaran simulasi digital, pembelajaran Group Investigation mudah diaplikasikan pada pokok bahasan perancangan model 3 dimensi. Pembelajaran ini dapat meningkatkan keterampilan sosial dimana siswa dilatih untuk saling bekerja sama dalam menyelesaikan tugas dari guru. Selain itu, pembelajaran ini dapat meningkatkan soft skill (kritis, komunikasi, kreatif) melalui investigasi diskusi kelompok. Proses investigasi menjadi lebih optimal karena didukung dengan berbagai sumber.Model pembelajaran kooperatif ini merupakan suatu pembelajaran yang menekankan kemampuan siswa untuk bekerja secara berkelompok. Model ini memberikan penekanan pada kemampuan siswa untuk bisa saling bekerja sama dan saling membantu dalam memahami materi pelajaran yang diajarkan atau menyelesaikan tugas yang diberikan (Joyoatmojo ,2015). Sutama (2007) menyatakan bahwa model pembelajaran group investigation merupakan pembelajaran berbasis kelompok yang memberikan peluang kepada siswa untuk berdiskusi, berfikir kritis, dan dapat bertanggung jawab dalam pembelajaran tersebut. Senada dengan apa yang dikemukakan oleh Santyasa (2009) dalam Wahyuningsih, dkk. (2012), bahwa pembelajaran investigasi kelompok mengarahkan aktivitas kelas yang berpusat pada siswa dan menyediakan peluang kepada guru menggunakan lebih banyak waktu untuk melakukan diagnosa dan koreksi terhadap masalahmasalah yang dialami oleh siswa (Artini ,2015).

Ratih, dkk (2012:71) menyatakan model pembelajaran Group Investigation dapat meningkatkan hasil belajar siswa lebih baik bila dibandingkan metode pembelajaran ceramah (Rizqi ,2017).

Berdasarkan uraian di atas, peneliti tertarik untuk melakukan penelitian tindakan kelas dengan judul "Implementasi Model Pembelajaran Kooperatif Tipe Grouplnvestigation untuk Meningkatkan Hasil Belajar pada Mata Pelajaran Simulasi Digital Siswa Kelas X SMK Negeri 1 Sukasada".

Tujuan penelitian ini adalah untuk mengetahui peningkatan hasil belajar siswa SMK Negeri 1 Sukasada pada mata pelajaran simulasi digital melalui implementasi model Pembelajaran Kooperatif Tipe GroupInvestigation.

Tujuan akhir proses pembelajaran adalah hasil belajar. Suratinah Tirtonegoro (2001: 43) menjelaskan bahwa hasil belajar merupakan penilaian hasil kegiatan belajar siswa dalam bentuk simbol, angka, maupun kalimat dalam periode tertentu.Pendapat ini sejalan dengan 
Djamarah (2008: 23) mengemukakan bahwa hasil belajar adalah hasil yang diperoleh berupa kesan-kesan yang mengakibatkan perubahan dalam diri individu sebagai hasil dari aktivitas belajar.

Hasil belajar yang diperoleh selama periode tertentu merupakan cerminan dari kemampuan siswa dalam menguasai pokok bahasan. Hasil dari tindak belajar siswa selama periode tertentu ditunjukkan dengan nilai tes yang diberikan guru. (Dimyati dan Mujiono, 2006: 36). Nilai tes diberikan oleh guru sebagai bentuk penghargaan atas usaha yang dilakukan siswa. Penghargaan diberikan atas dasar perubahan yang terjadi selama proses belajar siswa. Seperti yang dijelaskan oleh Oemar Hamalik (2001: 159) bahwa hasil belajar menunjukkan pada prestasi belajar.Sedangkan prestasi belajar merupakan indikator adanya perubahan tingkah laku siswa.Dari uraian tersebut, dapat disimpulkan bahwa hasil belajar adalah penilaian hasil kegiatan belajar siswa yang diberikan oleh guru berupa angka, simbol, dan kalimat yang didapatkan berdasarkan perubahan kemampuan kognitif, psikomotorik, dan afektif.

Simulasi digital adalah salah satu mata pelajaran yang diberikan kepada siswa kelas $X$ Sekolah Menengah Kejuruan (SMK) di jurusan akutansi, administrasi perkantoran, pemasaran, akomodasi perhotelan, usaha perjalanan wisata, dan multimedia. Materi simulasi digital diberikan untuk membekali mereka dalam memasuki dunia kerja sesuai dengan bidangnya. Setelah menempuh atau lulus dari mata pelajaran ini diharapkan siswa tidak hanya memahami hal-hal yang berkaitan dengan simulasi digital tetapi juga dapat menghubungkan konsep yang diperoleh dengan kenyataan yang ada dilapangan.

Group Investigation atau investigasi kelompok merupakan tipe pembelajaran kooperatif yang mengutamakan kerja kelompok dalam menginvestigasi kasus untuk mendapatkan informasi dari berbagai sumber. Menurut Sharan (dalam Slavin, 2005: 24) mengemukakan bahwa Grouplnvestigationmerupakan perencanaan kelas dalam kegiatan belajar dimana siswa dibentuk dalam kelompok kecil untuk menyelesaikan tugas yang diberikan guru.

Eggen dan Kauchak (dalam Maimunah, 2005: 21) menjelaskan bahwa Group Investigationadalah strategi belajar kooperatif yang menempatkan siswa ke dalam kelompok untuk melakukan investigasi terhadap suatu topik. Investigasi dilakukan oleh masing-masing siswa baik secara online maupun offline. Topik atau bahasan yang telah didapatkan siswa kemudian didiskusikan di dalam kelompok. Diskusi kelompok akan menumbuhkan sikap demokratis dalam menyelesaikan permasalahan. Proses pembelajaran yang dilandasi oleh nilai-nilai demokrasi, yaitu: penghargaan terhadap kemampuan, menjunjung keadilan, menerapkan persamaan kesempatan, dan memperhatikan keberagaman peserta didik (Budimansyah, 2007: 7). Dari uraian di atas, dapat diambil kesimpulan bahwa Grouplnvestigation adalah teknik pembelajaran kooperatif yang mengutamakan kelompok dalam kegiatan belajar. Kelompok ini bertujuan untuk menyelesaikan masalah dengan cara investigasi terhadap topik atau bahasan tertentu.

Pelaksanaan tahap pembelajaran harus sesuai dengan prinsip pengelolaan dari model pembelajaran kooperatif tipe Group Investigation. Dalam tipe Grouplnvestigation, pengajar berperan sebagai konselor dan konsultan. Peran pengajar yakni membimbing dan mengarahkan kelompok sesuai dengan kerangka tahapan

berikut ini: 1) Tahap pemecahan masalah, tahap ini berkenaan dengan proses menjawab pertanyaan, apa yangmenjadi hakikat masalah, dan apa yang menjadi fokus masalah. Permasalahan dianalisis ke dalam bentuk kerangka berfikir yang sistematis, 2) Tahap pengelolaan kelas tahap pengelolaan kelas berkenaan dengan proses menjawab pertanyaan,informasi apa yang saja yang diperlukan, bagaimana mengorganisasikankelompok untuk memperoleh informasi, 3) Tahap pemaknaan secara perseorangan, tahap ini berkenaan dengan proses pengkajian bagaimana kelompokmenghayati kesimpulan yang dibuatnya, dan apa yeng membedakan seseorangsebagai hasil dari mengikuti proses tersebut.

Menurut Slavin (2005: 218) dalam Group Investigation para muridbekerja melalui enam tahap yaitu:1) Mengidentifikasikan topik dan mengatur murid ke dalam kelompok, 2) Merencanakan tugas yang akan dipelajari, 3) Melaksanakan investigasi, 4) Menyiapkan laporan akhir, 5) Mempresentasikan laporan akhir6) Evaluasi.

Sharan (dalam Supandi, 2005: 6) mengemukakaan langkah-langkah pembelajaran pada model pembelajaran Group Investigation sebagai berikut:

(1) Guru membagi kelas menjadi beberapa kelompok yang heterogen. (2) Guru menjelaskan maksud pembelajaran dan tugas kelompok yang harus dikerjakan. (3) Guru memanggil ketua-ketua kelompok untuk memberikan materi tugas. (4) Masing-masing kelompok membahas materi tugas. (5) Setelah selesai, masing-masing kelompok yang diwakili salah satu anggota menyampaikan hasil pembahasannya. (6) Kelompok lain dapat memberikan 
tanggapan terhadap hasil pembahasannya. (7) Guru memberikan penjelasan singkat (klarifikasi) bila terjadi kesalahan konsep dan memberikan kesimpulan. (8) Evaluasi.

\section{Metode}

Penelitian ini dilaksanakan di kelas X MM2 SMK Negeri 1 Sukasada Kabupaten Buleleng dari bulan maret sampai mei tahun ajaran 2018/2019 sebanyak dua siklus. Jenis penelitian ini adalah penelitian tindakan kelas yang terbagi dalam empat tahapan yaitu perencanaan, pelaksanaan, pengamatan, dan refleksi seperti dijelaskan sebagai berikut Tahap 1: Perencanaan Tindakan(Planning), pada tahap ini, peneliti bersama guru merencanakan kebutuhan penelitian yang akan digunakan dalam proses pembelajaran model Group Investigation. Kebutuhan tersebut meliputi: materi ajar, modul ajar, tugas, RPP, Silabus, dan instrument, Tahap 2: Pelaksanaan Tindakan (Acting), Pada tahap ke-2 merupakan implementasi atau penerapan dari perencanaan yang telah dibuat pada tahap ke-1. Pada tahap ini, guru harus melaksanakan pembelajaran sesuai perencanaan yang telah dibuat bersama.Sedangkan peneliti bertindak sebagai kolaborator. Guru dan peneliti bekerja sama dalam melaksanakan pembelajaran model Group Investigation supaya hasil pembelajaran dapat tercapai secara maksimal, Tahap 3: Pengamatan(Observing), kegiatan pengamatan dilakukan ketika proses pembelajaran sedang berlangsung atau pada tahap pelaksanaan. Pengamatan dilakukan oleh guru dan peneliti untuk mengambil data keterampilan psikomotorik siswa dan sikap belajar siswa selama proses pembelajaran. Jadi, pada tahap ini guru dan peneliti sebagai observer atau pengamat, Tahap 4: Refleksi(Reflecting), kegiatan refleksi merupakan kegiatan untuk mengemukakan kembali proses pembelajaran yang telah dilakukan. Kegiatan ini dilakukan setelah guru dan peneliti selesai melaksanakan pembelajaran dengan model Grouplnvestigation. Pada tahap ini dilakukan evaluasi pelaksanaan pembelajaran.Setelah itu, guru dan peneliti mendiskusikan implementasi rancangan tindakan selanjutnya.

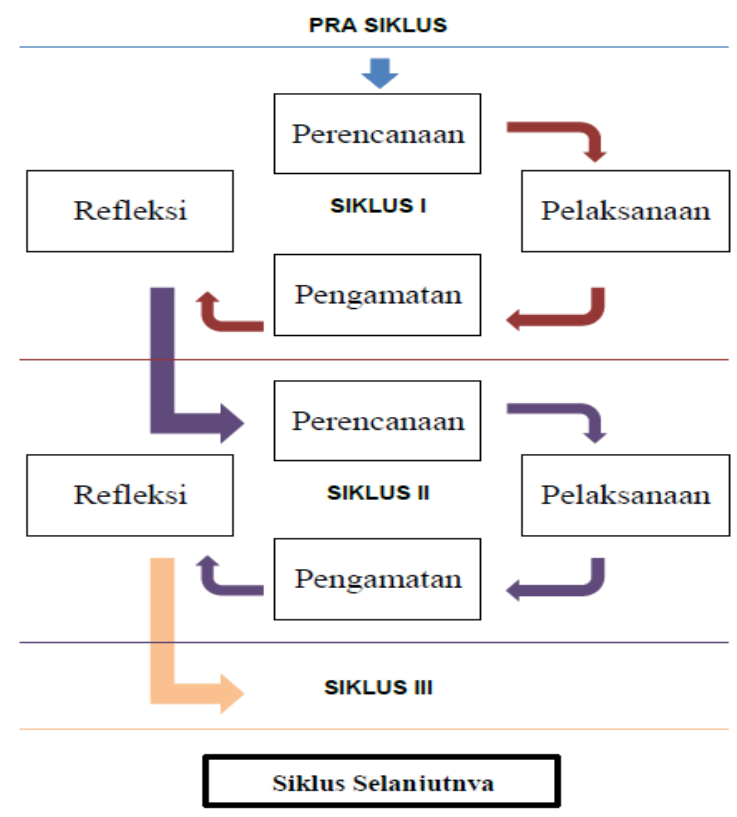

\section{Gambar 1 Siklus Penelitian}

Teknik observasi digunakan untuk mendapatkan data mengenai keterampilan psikomotorik dan afektif siswa selama pembelajaran berlangsung. Keterampilan psikomotorik yang diamati berupa: ketepatan penggunaan viewport, kemahiran penggunaan editing tools, kesesuaian pewarnaan objek, kemahiran menggunakan teknik rigging, ketepatan pengerjaan tugas, penyampaian hasil proyek, sedangkan afektif siswa yang dinilai berupa: memberikan tanggapan, kehadiran, disiplin tugas, tanggung jawab, kecermatan, kerja sama, dan kesopanan. Dokumentasi yang digunakan adalah video dan foto-foto kegiatan, daftar nilai, daftar hadir siswa selama proses pembelajaran berbasis proyek berlangsung, perangkat 
pembelajaran, serta dokumen penelitian yang digunakan selama penelitian. Tes digunakan untuk mendapatkan data nilai hasil belajar kognitif siswa, yang nantinya hasil dari aspek kognitif.Tes dilakukan tiap akhir Siklus.Soal yang digunakan dalam metode ini merupakan soal pilihan ganda sebanyak 25 soal.

Data yang dikumpulkan dalam penelitian ini adalah hasil belajar siswa terhadap pembelajaran yang dilakukan guru yaitu menerapkan model pembelajaranGroup Investigation.Instrumen tes hasil belajar yang digunakan dalam penelitian ini tertera pada tabel berikut.

Tabel 1. Instrumen Penelitian

\begin{tabular}{llll}
\hline Variabel & Metode & Alat/Instrumen & Sumber \\
\hline Hasil belajar siswa mata & Diskusi, tanya & $\begin{array}{l}\text { Perangkat Tes Hasil } \\
\text { pelajaran Simulasi Digital }\end{array}$ & Selajar, lembar \\
& $\begin{array}{l}\text { jawab, dan } \\
\text { penugasan }\end{array}$ & $\begin{array}{l}\text { observasi } \\
\end{array}$
\end{tabular}

Data yang telah dikumpulkan dianalisis dengan menggunakan metode analisis deskriptif kuantitatif karena data yang dikumpulkan berupa skor dalam skala interval yang dituangkan dalam bentuk tabel dan grafik. Metode ini digunakan untuk menentukan tingkatan tinggi rendahnya hasil belajar siswa secara klasikal yang dikonversikan ke dalam Penilaian Acuan Patokan (PAP) skala lima sebagai berikut (Candiasa, 2011b: 45).

Tabel 2. Ketentuan Analisis Hasil Belajar dalam Skala Lima

\begin{tabular}{ll}
\hline Rentangan & Kriteria \\
\hline $\bar{X} \geq M i+1,8 S D i$ & Sangat baik \\
$M i+0,8 S D i<\bar{X}<M i+1,8 S D i$ & Baik \\
$M i-0,6 S D i<\bar{X}<M i+0,6 S D i$ & Cukup baik \\
$M i-1,8 S D i<\bar{X}<M i-0,6 S D i$ & Kurang baik \\
$\bar{X}<M i-1,8 S D i$ & Sangat kurang baik \\
\hline
\end{tabular}

Dengan,

MI $=\frac{\frac{1}{2}}{\text { (Skor tertinggi ideal }+ \text { skor terendah ideal) }}$
$S D_{i}=\frac{1}{3} \mathrm{Ml}$

Analisis data hasil belajar siswa dianalisis secara deskriptif kuantitatif. Dalam analisis ini akan dicari rata-rata skor hasil belajar siswa secara klasikal dengan menggunakan rumus sebagai berikut.

Menghitung rata- rata skor hasil belajar siswa. Adapun rumusnya adalah:

$$
\overline{\mathrm{X}}=\frac{\sum \mathrm{X}}{N}
$$

(Dantes, 2012: 200).

Keterangan :

$\begin{array}{ll}\bar{X} & =\text { Rata-rata skor hasil belajar siswa } \\ \sum \mathrm{X} & =\text { Jumlah skor hasil belajar siswa } \\ N & =\text { Jumlah siswa }\end{array}$

Analisis Hasil Belajar secara individu, rumus yang digunakan adalah: 


$$
\text { Nilai Akhir Siswa }=\frac{\text { Jumlah skor yang diperoleh }}{\text { Jumlah skor maksimal ideal }} \times 100
$$

Tingkat Ketuntasan Belajar (KB) secara klasikal menggunakan rumus sebagai berikut.

$$
\mathrm{KB}=\frac{\text { Jumlah siswa y ang tuntas }}{\text { Jumlah siswa keseluruhan }} \times 100 \%
$$

Keterangan :

$\mathrm{KB}=$ Ketuntasan Belajar

Tabel 3. Kriteria Tingkat Penguasaan Kompetensi SMK N 1 Sukasada

\begin{tabular}{ccll}
\hline $\begin{array}{c}\text { Tingkat Penguasaan } \\
\text { Kompetensi }\end{array}$ & $\begin{array}{c}\text { Nilai } \\
\text { Huruf }\end{array}$ & \multicolumn{1}{c}{ Kategori } & \multicolumn{1}{c}{ Keterangan } \\
\hline $95 \%-100 \%$ & A & Sangat Baik & Tuntas \\
$86 \%-94 \%$ & B & Baik & Tuntas \\
$77 \%-85 \%$ & C & Cukup & Tuntas \\
$68 \%-76 \%$ & D & Kurang & Tidak tuntas \\
$59 \%-67 \%$ & E & Sangat kurang & Tidak tuntas \\
\hline
\end{tabular}

Metode analisis data aspek afektif dan psikomotorik

Analisis data aspek afektif dan psikomotorik menggunakan rumus sebagai berikut.

$$
N=\frac{S D}{S M} x 4
$$

(Sugiyono, 2013: 137)

Keterangan:

$\mathrm{N}=$ nilai aspek afektif/psikomotorik

$\mathrm{SD}=$ Skor yang diperoleh siswa

$\mathrm{SM}=$ Skor maksimal

Tabel 4 Kriteria Klasifikasi Aspek Afektif dan Psikomotorik Siswa

\begin{tabular}{cc}
\hline Capaian Optimum & Kriteria \\
\hline $3,00<\mathrm{N} \leq 4,00$ & SB (Sangat Baik) \\
$2,00<\mathrm{N} \leq 3,00$ & $\mathrm{~B}$ (Baik) \\
$1,00<\mathrm{N} \leq 2,00$ & $\mathrm{C}$ (Cukup) \\
$0,00<\mathrm{N} \leq 1,00$ & $\mathrm{~K}$ (Kurang) \\
\hline
\end{tabular}

Secara keseluruhan tindakan ini dikatakan berhasil apabila mencapai skor secara individu sesuai dengan KKM yang ditetapkan yakni $\geq 77$. Sedangkan ketuntasan belajar secara klasikal $\geq 77 \%$ sesuai KKM mata pelajaran simulasi digital kelas X MM2 SMK Negeri 1 Sukasada pada aspek kognitif, sedangkan aspek afektif dan psikomotorik minimal mencapai kriteria baik (B).

\section{Hasil Dan Pembahasan}

Kegiatan penelitian tindakan kelas ini dilaksanakan pada tanggal bulan maret sampai mei tahun ajaran 2018/2019 pada siswa kelas XMM2 SMK Negeri 1 Sukasada tahun pelajaran 2018/2019 dengan jumlah siswa 36 orang. Secara umum pelaksanaan pembelajaran di dalam kelas selama penelitian ini telah berlangsung sesuai dengan rencana pembelajaran yang telah disusun sebagai implementasi model pembelajaranGrouplnvestigation. Penelitian ini 
dilaksanakan dalam 2 siklus, dimana tiap siklus dilaksanakan dalam 3 kali pertemuan yaitu 2 kali pertemuan untuk pembelajaran dan 1 kali pertemuan untuk tes hasil belajar. Adapun hasil dan analisis data mengenai hasil belajar akan dijelaskan sebagai berikut.

Hasil penelitian pra siklus dilakukan observasi terhadap hasil Ujian Tengah Semester Siswa kelas XMM2 semester I yang masih di bawah kriteria ketuntasan minimal yaitu 77 untuk aspek kognitif (ketuntasan klasikal sebesar 58\%). Berdasarkan hasil observasi maka dilakukan upaya perbaikan pembelajaran untuk meningkatkan hasil belajar siswa dengan mengimplementasikan model pembelajaran Grouplnvestigation di siklus I dan siklus II.

Adapun yang mengakibatkan hasil belajar siswa kurang maksimal di kelas X MM2 SMK Negeri 1 Sukasada tahun ajaran 2018/2019 yaitu sebagai berikut. Pertama, pembelajaran masih berpusat pada guru, hal ini disebabkan karena siswa tidak memiliki persiapan sebelum mengikuti pembelajaran. Siswa jarang membaca buku sebelum pembelajaran dimulai sehingga guru mengambil metode ceramah untuk menjelaskan materi kepada siswa.Pengetahuan masih ditransformasikan secara utuh dari pikiran guru kepikiran siswa.Hal ini berarti siswa hanya mendapat pengetahuan dan pemahaman yang terbatas pada informasi yang diberikan oleh gurunya.

Kedua, kemauan bertanya dan rasa ingin tahu siswa sangat kurang, karena pengetahuan awal yang dimiliki oleh siswa relatif masih kurang.Sehingga jika siswa diberikan suatu permasalahan itu sendiri siswa kebingungan karena kurang tahu harus mulai dari mana mereka bekerja.

Ketiga, pembelajaran masih cenderung menggunakan metode ceramah, tanya jawab dan pembelajaran menggunakan diskusi kelompok jarang dilakukan.

Keempat, siswa merasa malu bertanya kepada guru. Hal ini disebabkan oleh siswa menganggap dirinya akan dicap sebagai siswa yang "bodoh" jika bertanya. Hal ini secara tidak langsung akan menyebabkan siswa semakin terpuruk dalam ketidaktahuannya terhadap konsep-konsep yang dijelaskan oleh gurunya.

Kelima, interaksi dan kerjasama siswa dalam menyelesaikan suatu permasalahan umumnya masih kurang dalam artian sikap individual siswa sangat tinggi.Sebagian besar siswa jarang melakukan tukar informasi dengan teman-teman dikelasnya dan tidak mau saling membantu dalam belajar.Ini terbukti saat siswa mengerjakan tugas atau soal yang diberikan oleh guru, Siswa cenderung mengerjakan secara mandiri.Siswa yang pintar cenderung tidak mau membimbing dan membantu temannya yang kurang kemampuan akademiknya, sebaliknya siswa yang merasa kurang mampu dalam pembelajaran enggan bertanya kepada siswa yang lebih mampu dengan alasan malu.

Keenam, guru belum begitu optimal memberdayakan aspek-aspek kompetensi dasar dalam kegiatan pembelajaran terutama aspek afektif dan psikomotor. Hal ini nampak dari jarangnya guru memantau siswa, baik sikap maupun keterampilan kerja ilmiah (praktikum) dalam proses pembelajaran, sehingga keterampilan proses tidak dapat dimunculkan secara optimal.

Maka berdasarkan permasalahan di atas, peneliti memiliki solusi pemecahannya dengan mengimplementasi model pembelajaran Group Investigation untuk meningkatkan hasil belajar siswa dalam mata pelajaran simulasi digital.

Sesuai dengan permasalahan dan tujuan dari penelitian ini, maka hasil yang ingin dicapai pada siklus I ini adalah mengenai hasil belajar siswa dalam pembelajaran simulasi digital.Siklus I ini dilaksanakan selama tiga kali pertemuan, yaitu dua kali pertemuan untuk pelaksanaan tindakan dan satu kali pertemuan untuk pelaksanaan tes hasil belajar.Adapun hasil yang diperoleh adalah sebagai berikut.

Data hasil belajar siswa pada sisklus I terdiri dari 3 aspek yaitu kognitif, afektif, dan psikomotorik. Hasil belajar siklus I disajikan dalam tabel berikut.

Tabel 5. Data Hasil Belajar Siswa Aspek Kognitif

\begin{tabular}{cclcc}
\hline No. & Rentang Skor & \multicolumn{1}{c}{ Kategori } & Jumlah siswa & Persentase \\
\hline 1 & $95 \%-100 \%$ & Sangat Baik & 22 orang & $61,11 \%$ siswa tuntas \\
2 & $86 \%-94 \%$ & Baik & & \\
3 & $77 \%-85 \%$ & Cukup & & \\
4 & $68 \%-76 \%$ & Kurang & 14 orang & $38,89 \%$ siswa tidak \\
5 & $59 \%-67 \%$ & Sangat Kurang & tuntas \\
\multicolumn{2}{l}{ Jumlah } & & 36 orang & $100 \%$ \\
\hline
\end{tabular}


Tabel 6. Data Hasil Belajar Siswa Aspek Afektif dan Psikomotor

\begin{tabular}{cccccc}
\hline Rentang Skor & Kategori & \multicolumn{2}{c}{$\begin{array}{c}\text { Aspek Afektif } \\
\text { Jumlah }\end{array}$} & $\begin{array}{c}\text { Aspek Psikomotor } \\
\text { Persentase }\end{array}$ & $\begin{array}{c}\text { Jumlah } \\
\text { Persentase }\end{array}$ \\
\hline $3,00<\mathrm{N} \leq 4,00$ & SB (Sangat Baik) & 30 & $83,33 \%$ & 29 & $80,56 \%$ \\
$2,00<\mathrm{N} \leq 3,00$ & B (Baik) & & & & \\
$1,00<\mathrm{N} \leq 2,00$ & C (Cukup) & 6 & $16,67 \%$ & 7 & $19,44 \%$ \\
$0,00<\mathrm{N} \leq 1,00$ & $\mathrm{~K}$ (Kurang) & & & & \\
\hline
\end{tabular}

Secara umum dapat disimpulkan bahwa penelitian tindakan pada siklus I, tingkat penguasaan materi secara klasikal pada materi simulasi digitalmencapai 61,11\% (aspek kognitif), 83,33\% (aspek afektif), dan 80,56\% (aspek psikomotorik). Jika dilihat berdasarkan rentang ketuntasan konversi nilai kelas X MM2 SMK Negeri 1 Sukasada maka hasil belajar siswapada aspek kognitif masih berada di bawah KKM yang ditetapkan yaitu 77 dan masih ada siswa yang berada di bawah kriteria baik untuk aspek afektif dan psikomotor, sehingga perlu dilakukan refleksi serta upaya perbaikan selanjutnya melalui siklus II.

Setelah melaksanakan tindakan siklus I kembali diadakan refleksi. Setelah diadakan fefleksi pada akhir siklus I ternyata terdapat kelemahan-kelemahan, diantaranya sebagai berikut 1) Siswa belum terbiasa mengikuti proses pembelajaran dengan mengimplementasikan model pembelajaranGrouplnvestigation, 2) Dalam diskusi kelompok masih terlihat ada siswa yang enggan untuk berdiskusi dengan teman sekelompoknya saat mengerjakan LKS, 3) Siswa masih belum aktif dalam mengikuti pelajaran hal ini terlihat ketika guru melontarkan pertanyaan yang menjawab hanya siswa itu-itu saja, 4) Sebagian besar siswa belum terbiasa menyimpulkan konsep-konsep yang telah dipelajari. Siswa masih mengalami kesulitan dalam membuat simpulan yang sistematis dan sesuai dengan yang diharapkan.

Mencermati permasalahan yang muncul maka dilakukan upaya perbaikan yaitu sebagai berikut 1) Memberikan motivasi kepada setiap kelompok tentang pentingnya kerjasama antar anggota kelompok dalam diskusi. Selain itu, guru juga mendatangi setiap kelompok sesering mungkin untuk mengawasi diskusi kelompok yang sedang berlangsung, 2) Memberikan motivasi kepada siswa mengenai manfaat dari pembelajaran yang sedang diterapkan guru. Hal ini untuk mendorong siswa agar lebih tertarik dalam mengikuti kegiatan pembelajaran yang diterapkan oleh guru, 3) Memberikan batas waktu maksimal dalam pengerjaan LKS serta memberikan teguran atau peringatan kepada kelompok yang mengerjakan LKS melebihi batas waktu, 4) Memberikan kesempatan kepada siswa yang kurang mampu untuk mengkomunikasikan hasil yang diperoleh, sehingga siswa bersangkutan merasa diperhatikan dan bila jawaban yang diberikan benar, hal ini akan memotivasi siswa bersangkutan, 5) Mengarahkan siswa dalam membuat simpulan dengan memberikan pertanyaan pancingan yang mengarah pada simpulan yang diharapkan. Dalam diskusi kelas, guru menunjuk siswa secara acak untuk menyimpulkan konsep-konsep yang telah dipelajari. Setiap siswa diberikan kesempatan untuk menanggapi simpulan temannya. Agar siswa tidak mengalami miskonsepsi guru memberikan penegasan.

Sama seperti pada siklus I, pada siklus II juga dilaksanakan selama tiga kali pertemuan yaitu dua kali pertemuan untuk pelaksanaan tindakan dan satu kali pertemuan untuk melaksanakan tes hasil belajar.Siklus II ini dilaksanakan berdasarkan penyempurnaan tindakan pada siklus I. Dengan melakukan perbaikan tindakan yang dilakukan pada siklus II baik dari aktivitas siswa maupun hasil belajar siswa. Adapun hasil yang diperoleh adalah sebagai berikut.

Data hasil belajar siswa pada sisklus II terdiri dari 3 aspek yaitu kognitif, afektif, dan psikomotorik. Hasil belajar siklus II disajikan dalam tabel berikut.

Tabel 7. Data Hasil Belajar Siswa Aspek Kognitif

\begin{tabular}{cclcc}
\hline No. & Rentang Skor & \multicolumn{1}{c}{ Kategori } & Jumlah siswa & Persentase \\
\hline 1 & $95 \%-100 \%$ & Sangat Baik & 31 orang & $86,11 \%$ siswa tuntas \\
2 & $86 \%-94 \%$ & Baik & & \\
3 & $77 \%-85 \%$ & Cukup & & \\
4 & $68 \%-76 \%$ & Kurang & 5 orang & $13,89 \%$ siswa tidak \\
5 & $59 \%-67 \%$ & Sangat Kurang & & tuntas \\
\hline & Jumlah & & 36 orang & $100 \%$ \\
\hline
\end{tabular}


Tabel 8. Data Hasil Belajar Siswa Aspek Afektif dan Psikomotor

\begin{tabular}{cccccc}
\hline Rentang Skor & Kategori & \multicolumn{2}{c}{$\begin{array}{c}\text { Aspek Afektif } \\
\text { Jumlah }\end{array}$} & $\begin{array}{c}\text { Pspek Psikomotor } \\
\text { Persentase }\end{array}$ & $\begin{array}{c}\text { Asmlah } \\
\text { Persentase }\end{array}$ \\
\hline $3,00<\mathrm{N} \leq 4,00$ & $\begin{array}{c}\text { SB (Sangat } \\
\text { Baik) }\end{array}$ & 36 & $100 \%$ & 36 & $100 \%$ \\
$2,00<\mathrm{N} \leq 3,00$ & $\begin{array}{c}\text { B (Baik) } \\
\text { C (Cukup) }\end{array}$ & 0 & $0 \%$ & 0 & $0 \%$ \\
$0,00<\mathrm{N} \leq 2,00$ & $\begin{array}{c}\text { K (Kurang) } \\
01,00\end{array}$ & & & & \\
\hline
\end{tabular}

Secara umum dapat disimpulkan bahwa penelitian tindakan pada siklus II, tingkat penguasaan materi secara klasikal pada materi simulasi digitalmencapai $86,11 \%$ berada dalam kategori baik (aspek kognitif), kategori baik (aspek afektif), dan kategori baik (aspek psikomotorik). Jika dilihat berdasarkan rentang ketuntasan konversi nilai kelas XMM2 SMK Negeri 1 Sukasada maka hasil belajar siswapada ketiga aspek sudah memenuhi kriteria ketuntasan minimal sehingga penelitian dapat dihentikan.

Setelah melaksanakan tindakan siklus II kembali diadakan refleksi. Setelah diadakan refleksi pada akhir siklus II ternyata kelemahan-kelemahan yang terjadi pada siklus I dapat teratasi, diantaranya sebagai berikut 1) Siswa belum terbiasa berdiskusi kelompok setelah dilakukan tindakan siklus II siswa sudah mulai bisa melakukan diskusi serta mulai mau mengemukakan pendapatnya masing-masing, 2) Siswa juga sudah terlihat aktif dalam pembelajaran hal ini terlihat ketika peneliti memberikan pertanyaan sudah banyak siswa yang bisa menjawab, 3) Disamping itu dalam proses pembelajaran siswa juga sudah mulai aktif, berani bertanya dan mengemukakan pendapat.

Mengacu pada hasil tindakan siklus II hasil belajar siswa juga sudah mengalami peningkatan dari siklus sebelumnya. Sehingga penelitian pada siklus II dihentikan karena sudah mencapai target yang diinginkan dan sesuai dengan jumlah rancangan siklus yang sudah direncanakan.

Berdasarkan hasil analisis data, implementasi model pembelajaran Group Investigation yang bertujuan untuk meningkatkan hasil belajar siswa kelas X MM2 SMK Negeri 1 Sukasada tahun ajaran 2018/2019.Adapun pembahasan hasilnya sebagai berikut. Berdasarkan analisis tentang data hasil belajar siswa dalam pembelajaran simulasi digital, diperoleh hasil pada siklus I yaitu rata-rata hasil belajar siswa pada aspek kognitif mencapai 78,11 dan tingkat ketuntasan belajar siswa secara klasikal sebesar $61,11 \%$. Sedangkan analisis hasil belajar siswa pada siklus II diperoleh rata-rata hasil belajar siswa mencapai 84,89 dan tingkat ketuntasan belajar secara klasikal sebesar $86,11 \%$

Dengan demikian dapat dilihat bahwa, rata-rata hasil belajar siswa pada siklus I mencapai 81,00 dan rata-rata hasil belajar siswa pada siklus II mencapai 84,89 jadi rata-rata hasil belajar siswa mengalami peningkatan sebesar 3,89 dan tingkat ketuntasan hasil belajar siswa secara klasikal pada siklus I mencapai $61,11 \%$ dengan kategori cukup baik dan pada siklus II tingkat ketuntasan hasil belajar siswa secara klasikal mencapai $86,11 \%$ dengan kategori baik jadi tingkat ketuntasan hasil belajar siswa secara klasikal pada siswa kelas X MM2 mengalami peningkatan sebesar $25 \%$.

Hasil belajar yang diperolah siswa sebelum dan sesudah diadakan tindakan siklus I dan siklus II, menunjukkan adanya peningkatan baik secara individu maupun secara klasikal. Hal ini disebabkan bahwa dalam pelaksanaan tindakan siklus II tidak lagi muncul kendala-kendala seperti pada siklus I. Hasil belajar siswa dapat mencapai target yang ditentukan sehingga penelitian ini dapat dihentikan.

Dalam proses pembelajaran siswa sudah terbiasa dan telah terlatih belajar dengan mengikuti implementasi model pembelajaran Group Investigation. Hal ini terlihat dari kegiatan yang dilakukan siswa, pada tahap memotivasi pikiran siswa, terlihat bahwa siswa sudah tertarik dalam mengikuti pembelajaran, mampu dan berani memberikan contoh-contoh terkait materi pembelajaran, dan berani mengemukakan pendapat di awal pembelajaran.Ini mengindikasikan bahwa siswa sudah termotivasi untuk belajar. Pada tahap menemukan informasi, siswa terlibat aktif menggunakan seluruh kemampuan yang dimilikinya untuk menemukan konsep-konsep yang melandasi jawaban dari pertanyaan yang diajukan dalam proses pembelajaran melalui diskusi kelompok dalam mengerjakan LKS. Tahap mencari makna, terlihat siswa sudah terbiasa dalam berdiskusi dengan teman kelompoknya dalam mencari pengertian maupun jawaban berdasarkan pertanyaan penuntun dari guru. 
Kegiatan siswa dalam berdiskusi di kelas dengan melakukan presentasi berdasarkan hasil diskusi kelompok, sudah saling membantu antar anggota kelompok, serius dalam diskusi kelompok, berani mengajukan pertanyaan, mengemukakan pendapat dan menanggapi pendapat temannya. Dengan adanya kegiatan ini maka siswa yang kurang pandai akan terbantu oleh teman-temannya yang sudah paham tentang materi. Tahap mendemonstrasikan pengetahuan terlihat ketika siswa mengemukakan pendapat dan pemikirannya ketika diberikan pertanyaan oleh guru terkait dengan kegiatan pembelajaran yang telah dilakukan.

\section{Kesimpulan}

Berdasarkan hasil penelitian dan pembahasan dapat disimpulkan bahwaPenerapan model pembelajaran Group Investigation pada mata pelajaran simulasi digital pokok bahasan simulasi 3 dimensi di kelas X MM2 SMK N 1 Sukasada dapat meningkatkan hasil belajar siswa pada aspek kognitif, aspek psikomotorik, dan aspek afektif.Berdasarkan hasil penelitian, saran yang diberikan untuk meningkatkan hasil belajar menggunakan metode Group Investigation adalah sebagai berikut: 1) Pengelolaan waktu yang digunakan untuk investigasi dan pengerjaan tugas diberikan sesuai dengan materi yang dibahas, 2) Pengarahan yang berupa materi dan tugas pembelajaran sebaiknya diberikan pada pertemuan sebelumnya, sehingga pada proses pembelajaran, waktu yang tersedia cukup untuk melakukan investigasi, 3) Proses investigasi sebaiknya didukung dengan fasilitas buku dan internet supaya mendapatkan berbagai macam sumber belajar, 4) Sebagai bahan pertimbangan model pembelajaran dalam pembelajaran Simulasi Digital untuk meningkatkan hasil belajar

\section{Daftar Pustaka}

Agung. 2005. Metodologi Penelitian Pendidikan Suatu Pengantar. Singaraja: Fakultas IImu Pendidikan Istitut Keguruan dan IImu Pendidikan Negeri Singaraja.

Agus Suprijono. 2009. Cooperative Learning Teori dan Aplikasi PAIKEM. Yogyakarta: Pustaka Belajar.

Ahmad Abu Hamid. 2009. Penelitian Tindakan, Penelitian Kelas, dan Penelitian Tindakan Kelas. Yogyakarta: Pusat PengembanganInstruksional Sains.

Asih. 2012.Model-Model Penelitian Tindakan Kelas. http://didaktik.artikelpendidikan.net. 27 Februari 2015 (22.10).

Artini (2015).Penerapan Model Pembelajaran Kooperatif Tipe Group Investigation Untuk Meningkatkan Aktivitas Dan Hasil Belajar Ipa Pada Siswa Kelas Vi Sd Inpres 1 Tondo .eJurnal Mitra Sains, Volume 3 Nomor 1, Januari 2015 hlm 45-52ISSN: 2302-2027

Dantes. 2012. MetodePenelitian. CV Andi Offset: Yogyakarta

Dimyati dan Mudjiono. 2002. Belajar dan Pembelajaran. Jakarta: PT Rineka Cipta.

Djamarah, S. B. 2002. Strategi Belajar Mengajar. Jakarta: Rineka Cipta.

Dwi Wahyuni, Fihrin, dan Muslimin. 2012. Efektivitas Model Pembelajaran Kooperatif Tipe Group Investigation terhadap Hasil Belajar Fisika pada Siswa Kelas XI MA Alkhairat Kalangkangan. Jurnal Pendidikan FisikaTadulako 2(1): 36.

Ekawarna. 2013. Penelitian Tindakan Kelas. Jakarta: GP Press Group.

Isjoni. 2009. Cooperative Learning. Badung: Alfa beta.

Joyoatmojo ,Soertano (2015). Penerapan Model Pembelajaran Group Investigation (Gi) Dengan Mind Mapping Untuk Meningkatkan Prestasi Belajar Ekonomi Siswa Sma Negeri 5 Surakarta Tahun Ajaran 2014/2015 .Jurnal FKIP Universitas Sebelas Maret.

Kunandar.2008. Langkah Mudah Penelitian Tindakan Kelas Sebagai Pengembangan Profesi Guru.Jakarta: Raja Grafindo Persada. 
Miftahul Huda. 2011. Cooperative Learning Metode, Teknik, Struktur, dan Penerapan. Yogyakarta: Pustaka Pelajar.

Nana Sudjana. 2011. Penilaian Hasil Belajar Mengajar. Bandung: PT Remaja Rosdakarya.

Nur Asma. 2006. Model Pembelajaran Kooperatif. Jakarta: Depdiknas.

Nurkholis (2013). Pendidikan Dalam Upaya Memajukan Teknologi .Jurnal Kependidikan, Vol. 1 No. 1 Nopember 2013.

Oemar Hamalik. 2001. Proses Belajar Mengajar. Jakarta: Bumi Aksara. Peraturan Menteri Pendidikan dan Kebudayaan Republik Indonesia Nomor 104Tahun 2014 tentang Penilaian Hasil Belajar.

Risqi ,Chera (2017). Penerapan Model Pembelajaran Group Investigation Terhadap Hasil Belajar Siswa Pada Materi Sistem Ekskresi Manusia .Jurnal Program Studi Pendidikan Biologi ISSN : 2338-7173 Februari 2017, Vol. 7,No. 1

Slamet. 2003. Belajar dan Faktor-Faktor yang Mempengaruhinya. Jakarta: PT Rineka Cipta.

Saptadi ,Iwan (2016). Penerapan Model Pembelajaran Kooperatif Tipe Group Investigation (Gi) Untuk Meningkatkan Hasil Belajar Fisika Siswa Kelas X Sma Negeri 2 Muara Beliti Tahun Pelajaran 2015/2016 .Jurnal STKIP-PGRI Lubuklinggau.

Slavin, R. E. 2005.Cooperative Learning Teori, Riset dan Praktek. Bandung: Nusa Media.

Sugiyanto. 2010. Model-Model Pembelajaran Inovatif. Surakarta: Yuma Pustaka.

Sugiyono. 2013. Metode Penelitian PendidikanPendekatan Kuantitatif, Kualitatif, dan R\&D. Bandung: Alfabeta.

Pendidikan Tinggi: Departemen Pendidikan Nasional.

Suharsimi Arikunto. 2010. Prosedur Penelitian Suatu Pendekatan Praktek. Jakarta: Rineka Cipta. 